\title{
О РАБОТЕ МЕЖДУНАРОДНОЙ КОНФЕРЕНЦИИ «ПРОСТРАНСТВО НЕ ТОЛЬКО ДЛЯ ЖИЗНИ...»
}

\author{
(C) 2019 г. Т.Н. Лошакова
}

8-10 апреля 2019 года в г. Берлине на базе Freie Universität (Свободный Университет) прошла международная конференция «Space not only for the living: Human remains at Bronze Age settlements in Eurasia». В работе конференции приняли участие ученые из 12 стран, было прочитано и обсуждено 28 докладов. Сообщения участников были посвящены формированию традиции погребений человека на поселениях эпохи бронзы и сложению связанных с ними верований. Ученые Казахстана были представлены исследователями из Института археологии им. А.Х. Маргулана, Сарыаркинского археологического института при Карагандинском государственном университете им. академика Е.А. Букетова и из Павлодарского государственного университета им. С. Торайгырова.

Ключевые слова: археология, Евразия, эпоха бронзы, международная конференция, поселение, погребения

В первой декаде апреля 2019 года в г. Берлине на базе Freie Universität (Свободный Университет) состоялась международная конференция «Space not only for the living: Human remains at Bronze Age settlements in Eurasia»* [*URL: https://www.topoi.org/wp-content/ uploads/2019/03/20190408_Space_Conference_Program.pdf]. В работе конференции приняли участие ученые из 12 стран: Германии, России, Казахстана, Болгарии, Испании, Молдовы, Польши, Румынии, Словении, Украины, Хорватии, Чехии.

На конференции было заслушано 28 докладов. Сообщения участников были посвящены формированию традиции погребений человека на поселениях эпохи бронзы и связанных с ними верований.
За последние десятилетия в связи с широкомасштабными исследованиями памятников эпохи бронзы мировая наука пополнилась огромным количеством материалов погребений людей, производившихся на поселениях. Благодаря этому сегодня можно совершенно точно утверждать, что у племен эпохи бронзы, обитавших на обширной территории, существовали обряды и традиции, связанные с сооружением погребений на площади «пространства живых». Перед научным сообществом встал вопрос о том, как классифицировать эти погребения - как культовое действие, ритуальное жертвоприношение? Кто эти люди? Выдающиеся соплеменники или иноплеменники? На эти и многие другие вопросы пытались найти ответ в своих докладах участники конференции. 


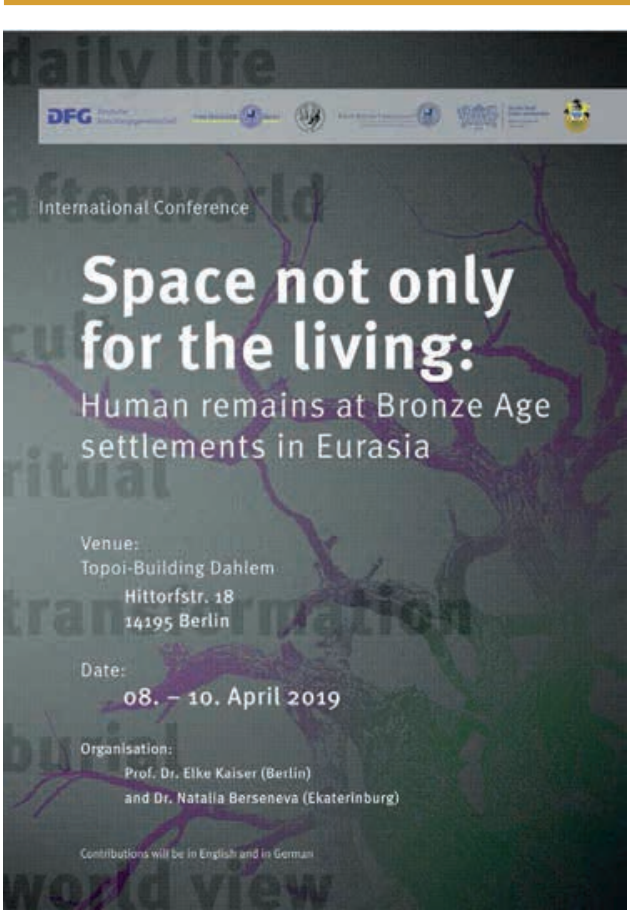

С приветственным словом к участникам собрания обратились его организаторы профессор Э. Кайзер (E. Kaiser) и Н. Берсенева.

Доклады и представленные в них материалы охватили огромную территорию, что позволило сформировать представление о сложении традиции погребений и сформировать мнение о связанных с этим действиях и верованиях.

Доклад профессора И. БейлкеФойгта (I. Beilke-Voigt) из Берлина содержал в себе вопросы теоретического обоснования формирования феномена погребений на поселениях. Профессор В. Губенсак (V. Hubensack) из Лейпцига представил материалы захоронений в шахтах на поселениях раннего бронзового века в центральной Германии. О формировании традиции погребения на поселениях эпохи бронзы, альтернативных погребальных практиках, а также выявлении отдельных костей человека на поселениях нижнего города Гюненбурга и государства Бра- уншвейг было доложено исследователями из Геттингена (Германия) профессорами И. Хеске (I. Heske) и С. Грефен-Петерсом (S. GrefenPeters). Материалы поселений долины Кочабамба представили в своем докладе ученые из Берлина О. Габельманн (O. Gabelmann) и Б. Тесманн (B. Teßmann).

Интрамуральным погребениям бронзового века юга Испании посвящен доклад профессора М. Бартельхайма (M. Bartelheim) (Тюбинген, Германия). Доклад испанского коллеги X. Ф. Торрес Мартинеса (J.F. Torres Martínez) освещал материалы поселений эпохи бронзы из северной провинции Испании, Кантабрии.

Блок докладов был посвящен материалам памятников эпохи бронзы Восточной Европы. Погребения человека на поселениях бронзового века Моравии освещены в докладе исследователей из Чешской республики Д. Пармы (D. Parma) и К. Шабатовой (K. Šabatová). Интерес вызвал доклад профессора К. Бакварова (K. Bacvarov) из Болгарии, посвященный погребениям на поселениях Фракии в эпоху раннего бронзового века. Вопросам формирования погребального пространства на поселении эпохи бронзы Брусчево на территории Польши посвящен совместный доклад профессора Дж. Кнейзеля (J. Kneisel) (Киль, Германия) и профессора М. Ягера (М. Jaeger) (Познань, Польша). Вопрос о захоронении человека как особого вида подношения (жертвоприношения) рассмотрен в докладе польских коллег профессора Я. Гурски (J. Górski) (Краков, Польша) и профессора П. Макаровича (Р. Makarowicz) (Познань, Польша).

В совместном докладе Б. Тебманн (В. Teßmann) (Берлин, Германия), К. Миховилич (К. Mihovilić) 
(Пула, Хорватия) и Б. Тержан (B. Teržan) (Любляна, Словения) представили материалы захоронений и находки человеческих костей на территории укрепленного поселения Монкодонья (Истрия, Хорватия), датирующегося периодом от раннего до среднего бронзового века.

Погребениям на поселениях восточной части Карпатского региона посвящен доклад исследователя из Румынии Ф. Гогэлтана (F. Gogăltan). Вопросам биоархеологии жизни и смерти на поселениях Добруджи в юго-восточной области Румынии в период с 1000 до 750 до н. э. посвящен доклад М. Константинеску (M. Constantinescu) и С.-С. Айлинкай (S.-C. Ailincai).

Представительная серия докладов была озвучена коллегами из России. Так, в докладе Н.А. Берсеневой были обобщены материалы погребений с поселений бронзового века Южного Урала, на основе которых рассматривались вопросы классификации этих объектов. В докладе А.А. Хохлова (Самара) и Е.П. Китова (Москва) было представлено необычное захоронение с поселения Малоюлдашево I, исследовавшего в Оренбуржье. Более обширно материалы погребений на поселениях эпохи бронзы Оренбургской области представлены в докладе Л. Купцовой и И.А. Файзуллина.

Погребения и антропология поселения Линево 1, расположенного в Западной Сибири, датирующегося переходным от бронзы к раннему железному веку периодом, подробно рассмотрены в докладе Л.Н. Мыльниковой (Новосибирск).

Вопросу «атипичных» погребений в культурном слое жилищ как атрибута взаимодействия срубной и андроновской популяций позднего бронзового века в Южном Зауралье был посвящен совместный доклад уфимцев И.А. Шутелевой, Н.Б. Щербакова, Т.А. Леоновой.

В докладе М. Кашубы (СанктПетербург) приведены и проанализированы материалы поселений к востоку от Карпат, датируемых началом раннего железного века (X-IX вв. до н.э.).

Украинские коллеги представили два доклада. В совместном докладе Р. Мимохода (Москва, Россия) и О. Загородней (Харьков, Украина) рассматривались поселенческие комплексы срубной культурно-исторической общности. Человеческим погребениям на поселениях скифского периода восточно-европейской лесостепи был посвящен доклад С. Гречко (Киев, Украина).

Вопросам изучения погребений на поселениях с традицией трупосожжения культуры поздней бронзы на территории Молдовы посвящен совместный доклад Е. Савы (Кишинев, Молдова) и Э. Кайзера (Берлин, Германия).

Казахстанские материалы были представлены двумя докладами. Авторы первого сообщения Э.Р. Усманова и В.К. Мерц* [*Название доклада в программе конференции: «The Pattern "Living Space for the Dead": from the Copper Age to the Nomads (based on materials from settlements in eastern Saryarka and Priirtysh'e)» - прим. авт.]. В доклад вошли материалы, полученные на стоянке Шидерты-3, поселениях Малокрасноярка, Усть-Нарым, Шауке-1, Икпень, а также памятниках Лисаковской округи. В сообщении Т.Н. Лошаковой рассматривались случаи демембрации, зафиксированные в погребениях людей на поселении Токсанбай в Северо-Восточном Прикаспии.

Для участников конференции профессор С. Хансен прочитал лек- 
цию «Захоронения на поселениях бронзового века», которая включила в себя материалы памятников Европы, Азии и Латинской Америки.

Участие в конференции такого уровня дает возможность не только расширить круг научных интересов благодаря живому общению с коллегами, но также позволяет обсудить волнующие вопросы, завязать новые научные контакты, ознакомиться с новыми материалами, достижениями и разработками.

\section{Сведения об авторе:}

Лошакова Татьяна Николаевна - старший научный сотрудник, Институт археологии им. А.Х. Маргулана (Алматы, Казахстан); loshakovat@mail.ru

\section{«КЕНІСТІК ТЕК ӨМІР СУРУ ҮШІН ҒАНА ЕМЕС...» АТТЫ ХАЛЫҚАРАЛЫҚ КОНФЕРЕНЦИЯ ТУРАЛЫ}

\section{Т.Н. Лошакова}

Берлин қаласының Тәуелсіз Университеті (Freie Universität) аясында 2019 жылдың сәуір айында «Кеңістік тек өмір сүру үшін ғана емес: Еуразияның қола дәуірі қоныстарындағы адам қалдықтары» (Space not only for the living: Human remains at Bronze Age settlements in Eurasia) тақырыбында халықаралық конференция өтті. Оған әлемнің 12 елінен келген ғалымдар қатысты. Конференцияда 28 баяндама оқылып, талқыға түсті. Қатысушылардың хабарламаларында қола дәуірі қоныстарындағы адамды жерлеу дәстүрінің қалыптасуы және соған байланысты сенімдер мен ғұрыптардың пайда болуы сөз болды. Осы конференцияға Ә.Х. Марғұлан атындағы Археология институтының, академик Е.А. Бөкетов атындағы Қарағанды мемлекеттік университеті жанындағы Сарыарқа археологиялық институтының және С. Торайғыров атындағы Павлодар мемлекеттік университетінің ғалымдар қатысты.

Түйін сөздер: археология, Еуразия, қола дәуірі, халықаралық конференция, қоныс, жерлеу орындары

\section{ON THE WORK OF THE INTERNATIONAL CONFERENCE "SPACE NOT ONLY FOR THE LIVING..."}

\section{T.N. Loshakova}

An international conference «Space not only for the living: Human remains at Bronze Age settlements in Eurasia» was held in Berlin at the Freie Universität in April 2019. Scientists from 12 countries attended the conference. 28 reports were presented and discussed. Participants' reports were devoted to the development of the human burials tradition in the settlements of the Bronze Age as well as associated with it beliefs and traditions. Researchers from the A.Kh. Margulan Institute of Archaeology, Saryarka Archaeological Institute at the academician E.A. Buketov Karagandy State University and S. Toraigyrov Pavlodar State University represented Kazakhstan at the conference. burials

Keywords: archaeology, Eurasia, Bronze Age, international conference, settlement,

About the Author:

Loshakova Tatyana N. Senior Researcher, A.Kh. Margulan Archeology Institute, Astana, Kazakhstan; loshakovat@mail.ru 